\title{
A New Discovery of Metazoa Imprints and Ichnofossils in the Vendian Mohyliv Suite from the Bernashivka Quarry
}

\section{Volodymyr Grytsenko}

National Museum of Natural History, NAS of Ukraine, Kyiv

\begin{abstract}
A New Discovery of Metazoa Imprints and Ichnofossils in the Vendian Mohyliv Suite from the Bernashivka Quarry. - Grytsenko, V. - The Vendian sequence of Podillia was concurrent with the Ediacaran sections as a stratotype for the last system of Upper Proterozoic. The sections are outcropped on banks of the Dniester River and its tributaries, but the best object for exploration is the quarry near Bernashivka village. Scientists and fossil diggers get new findings - samples of the Vendian biota. Even fossil diggers have better conditions for work, because they are independent from any institution. The objects of our study were various fossils (remains of Metazoa, ichnofossils and bioglyphs), which were found on a few levels of the Vendian sequence. New species were described on standard adopted for the Vendian fossils. Perhaps, some of these casts of animals may belong to coral polyps. Two species of Charnia (Ch. ivantsovi sp. nov. and Ch. masoni Ford) were found first this spring in the Yampil beds. Besides the fossils, facial affinities of surrounding rocks were studied. The sequence reflects different marine conditions in the past from the shallow to the deep water. Fossil remains were spread mostly in shallow water deposits.

Key words: Vendian, Upper Proterozoic, Podillia, Mohyliv formation, new genera, new species.
\end{abstract}

\section{Introduction}

The Vendian sequence of Podillia was concurrent with the Ediacaran section as a stratotype for the last system of Upper Proterozoic. Both stratigraphical successions have positive and negative peculiarities (Кирьянов, 1993; Великанов, 2011). The Ediacaran referent section is divided from the Cambrian by stratigraphical interruption, which is not clear in size. The best Vendian referent section is outcropped along the Dniester River and its tributaries (Великанов, 1985). The section is represented by terrigenous sediment rock intercalations (thin and thick: sandstone, siltstone, argillite and rare gravelite), which complete two series - Mohyliv-Podilskiy and Kanylivka (Коренчук, 1981). The first series (group) includes three suites (= "formations" in English terminology): Mohyliv, Yaryshiv and Nagoriany. The second series consists of four suites: Danilivka, Zharnivka, Krushanivka and Studenitsa (Великанов и др., 1983).

In this paper we describe new unusual fossils from the Mohyliv suite (formation) mostly from the Lomoziv beds (member).

\section{Geological setting}

One of the best sections was opened in the Bernashivka quarry on the left bank of the river opposite to Novodniestrovsk. Terrigenous sediments are represented by coarse and thin grain sandstones, siltstones, and mudstones (argillites) form the interbedding and separate riders. The section is represented by the Mohyliv suite which is divided into the following beds: Olchedaiv, Lomoziv, Yampil' and Liadova. The Olchedaiv beds are absent in the quarry because of positive relief of the basement. The granite ledge was a hard base for the Dniester hydropower station. The lower part of the Vendian section in the quarry is represented by the Lomoziv beds. The Olchedaiv beds (base part of the Mohyliv sequence) have appeared in other sections westwards and southwards. Bernashivka Island existed from the Groushka time (early Vendian) until the beginning of the Yampil' time (late Vendian). The Lomoziv beds are represented by interbedding siltstones and thin interlayers of quartz sandstone

Corresponding author address: National Museum of Natural History, NAS of Ukraine; Bohdan Khmelnytsky St. 15, Kyiv, 01601 Ukraine; e-mail: favosites@ukr.net 
overlaying on the slope of the ledge and the Yampil' beds on it top. Thus, the Lomoziv beds flank to the Vendian hill forming a pinch. Such position is a reason for quartz concentration by erosion of the granite ridge (Великанов и др., 1983).

\section{Material and methods}

The objects of our study were different fossils (remains of Metazoa and ichnofossils or bioglyphs) found and collected in the Mohyliv suite on a few levels of the Vendian sequence. They are so-called "vendobiontes" including imprints of soft body animals and track fossils. All objects were visible on plates with different size and thickness. The plates were pictured in light with a very small angle to emphasize the thin relief. Then differently shaped pictures were collected into separate groups and compared with known species. The new species were described according to the standard adopted for Vendian fossils. Besides the fossils, facial affinities of surrounding rocks were studied as well.

\section{Results of the study}

The Bernashivka quarry has formed during three decades in the result of comparatively small explosions and excavations of the stones. Every year the quarry became bigger and deeper. A whole sedimentary section of the Mohyliv suite was opened, except the Olchedaiv beds which were not deposited there. More than ten meters of Proterozoic granites and migmatites were excavated from the quarry under sedimentary rocks. Lots of fossils spread in some levels of the quarry sequence were found just buried in the Lomoziv and Yampil' beds. New species of ichnofossils and imprints of soft body animals were discovered among usual others. The total number of collected specimens is more than 2000 samples. We described here fourteen new species belonging to thirteen new genera. Descriptions were fulfilled in open nomenclature in manner traditionally used for such objects. The description is arranged into two parts: imprints and ichnofossils without determination of higher systematic categories.

\section{Description of the new macrofossils and ichnofossils}

All specimens are conserved in the monographic collections hall of the Department of Geology, NMNH NAS of Ukraine.

\section{Genus Cyclomedusa Sprigg, 1947 \\ Cyclomedusa leonidi Grytsenko sp. nov. (Fig. 1)}

Description. It is a round, almost flat body imprint, with diameter up to $20 \mathrm{~cm}$ and unclear borders. Rugous rings are visible on the surface near the edge and in the middle. A little cycle could be seen at the center of the mold. The imprint is conserved as a negative epirelief. The rock included it is a thin grain silt-argillite.

Comparison. The new species differs from other Cyclomedusa by its bigger disc, very low relief and absence of dividing into some clear cycles (Заика-Новацкий и др., 1968; Палий, 1969; Paliy et al., 1983). Remarks. The name of the species was given in memory of our colleague and friend, a famous Ukrainian paleontologist Leonid Konstantinenko. Original — No 2514-296.

The original specimen was found in the southern part of the quarry in the upper part of the Lomoziv beds.

Such imprints could be also interpreted as a mold of a bacterial colony.

Stellaria lomozoviensis Grytsenko gen. et sp. nov. (Fig. 2)

Description. This is a stellate imprint of an unknown animal remained as a negative epirelief. An oval crest surrounded by sulcus is at the center of the cast. Dichotomised appendages are oriented from the oval crest. The width of the specimen is near $2 \mathrm{~mm}$, length - up to $6-7 \mathrm{~mm}$. The total diameter of the cast is near $20 \mathrm{~mm}$. 
Comparison. It differs from Hiemalora stellaris Fedonkin by its little size, absence of central disc and less number of tentacle-shaped appendages. The new taxon differs from Virgatia leonidi Grytsenko gen. et sp. nov. (described here) by smaller size and absence or less expressed tentacle-shaped appendages.

Remarks. The original specimen is conserved in the collections of NMNH NAS of Ukraine, Department of Geology, coll. No. 2489-91. The generic name was given according to its star-shape look. The species name is derived from the Lomoziv beds.

\section{Olgerdina einori Grytsenko gen. et sp. nov. (Fig. 3)}

Description. The cast was collected as a positive hyporelief. It is an oval body imprint. Its size is $25 \times 30 \mathrm{~mm}$ and it consists of three oval rings. The external ring is broad $(7 \mathrm{~mm})$, and the middle one is $1.5 \mathrm{~mm}$, while the interior one is near $1 \mathrm{~mm}$ in width. The prick on the periphery is up to $2.5 \mathrm{~mm}$ in width. It is limited from outward by narrow salient limbs. The oval prick is situated in the central part of the cast. Its size is $10 \times 18 \mathrm{~mm}$.

Comparison. The species differs from all other known genera and species.

Remarks. Generic and species names were given in memory of Olgerd Leonard Einor, a famous expert on Carboniferous stratigraphy and paleontology (brachiopods), chairman of the department of paleontology and geology at Taras Shevchenko Kyiv National University.

The original specimen's ID - No. 2489/440. It was collected from the Bernashivka quarry; Vendian of Podillia (compared with Ediacaran of Australia), Mohyliv-Podilskiy series (group), Mohyliv suite (formation), Lomoziv beds (unit).

\section{Astra elongata Grytsenko gen.et sp. nov. (Fig. 4)}

Description. The cast is a complicate texture among the little ones of Nemiana simplex Palij. Three jointed gently prominent rounded petals arranged at the central area of the animal cast. Elongate lobs of different size join to the central area. Two wide and long lobs are set along the axis from one side and two similar elements are located from the other side. Six shorter lobs are located among them (three from each side). It is oriented obliquely to the imaginary axis of the animal.

Remarks. It is possible to find some resemblance to a primitive blind miomera trilobite. We could not know any similar species among the Vendian animals. The described species is represented by a single specimen. The generic name was given because of the flower-shaped cast. The species name was given due to elongate contour of the cast. Original Coll. No. 25425-206

Charnia ivantsovi Grytsenko sp. nov. (Fig. 5-6)

Description. A frond-like form belonging to genus Charnia without full mod preservation. It was found as a positive imprint at the lower surface of the layer together with casts of Nemiana simplex Palij. The surface shows result of visible water turbulence which is reflected on the layer, and possibly was a reason of making ill-conditioned preservation of such big imprints. The animal's body had complicated bilateral structure including salient axes up to $40 \mathrm{~mm}$ of length connected one to another like a chevron and linked by short parallel bulkheads. Distances among the axes are $7-8 \mathrm{~mm}$. The median axis is absent. The angle between the axes is near $85^{\circ}$. Eight axes are distinguishable on the left part of the cast, while two lower ones could be discernible because of existing bulkheads. These axes were not imprinted or disappeared. The distance between the bulkheads is near $2 \mathrm{~mm}$. The apical part and the base of the "frond" are not preserved. Thus, the total length of the cast could be much more than $18 \mathrm{~cm}$.

There are visible imprints of disks on the plate which could be attaching structures of other absent fronds.

Comparison. The described species differs from others by the structure of the cast. The widespread C. masoni Ford has smaller angle between the axes (near $65^{\circ}$ ), while C. grandis is much bigger (Antcliffe and Brasier, 2007, Brasier, Antcliffe, 2004). 
Remarks. The sample was found by a fossil-digger D. Pylypenko on the surface of a thin bedded sandstone in the northern part of the quarry running from the upper part of the Yampil beds. The unique specimen was collected by a private person, but the staff of the Department of Geology, NMNH NAS of Ukraine expects its donation to display in a special hall of monographic collections. The species name was given in honor of Andrei Ivantsov, a famous paleontologist, senior scientific researcher of Borissiak Paleontological Institute of the Russian Academy of Sciences.

S. Finko found a fragment of real Ch. masoni Ford possibly on the same level in April 2016.

\section{Genus Bernashevia Grytsenko gen. nov.}

Diagnose. A little psammocorall of size 5-5.5 $\mathrm{mm}$ in diameter. They formed communities on the clayey bottom. Round holes with crest in the center (negative epirelief) are visible on the cast.

\section{Bernashevia einori Grytsenko gen. et sp. nov. (Fig. 7)}

Description. Little specimens remained as negative epireief looking like rounded halls with crest in the center.

The central crest is usually lower than the depth of the holes. The diameter of the rings is from 2 up to $5-5.5 \mathrm{~mm}$. Some of them could be seen with scarcely observable oriole up to $20 \mathrm{~mm}$ in diameter. The distance among the casts differed from 2 up to $10 \mathrm{~mm}$ and even more.

Original. Coll. - No. 2514-23.

\section{Amorphia incognita Grytsenko gen. et sp. nov. (Fig. 8)}

Description. Imprints of unknown animals of irregular form are on the bed's surface (positive hyporelief). Hypothetically, the holes were filled up by sedimentary material which covered a community. The holes have different size (from 2 up to $8 \mathrm{~mm}$ ). They have subglobose and extended form, sometimes two or even three are connected by edges.

Remarks. The author consider these forms as a special type of worm bioproductions.

\section{Cocardia valerii Grytsenko gen et sp. nov. (Fig. 9)}

Description. These are two inscribed into one another gibbous ovals. The internal oval was damaged. An oxidized iron mineral (probably past pyrite) is visible on its surface. The total dimensions of the cast are $25 \times 30 \mathrm{~mm}$. The width of the external oval is near $8 \mathrm{~mm}$. Dimensions of the inner one are $15 \times 20 \mathrm{~mm}$. The form was conservated as a positive hyporelief.

Fig. 1. Cyclomedusa leonidi Grytsenko sp. nov. on a siltstone plate. Here is a remained fragment of the thin layer covering the cast.

Рис. 1. Cyclomedusa leonidi Grytsenko sp. nov. на плитці алевроліту. В центрі відбитку зберігся фрагмент тонкого покриваючого відбиток шару.

Fig. 2. Stellaria lomozoviensis Grytsenko gen. et sp. nov. Рис. 2. Stellaria lomozoviensis Grytsenko gen. et sp. nov.

Fig. 3. Olgerdia einori Grytsenko gen. et sp. nov. Pис. 3. Olgerdia einori Grytsenko gen. et sp. nov. Fig. 4. Astra elongata Grytsenko gen.et sp. nov. Рис. 4. Astra elongata Grytsenko gen.et sp. nov.

Fig. 5-6. Charnia ivantsovi Grytsenko sp. nov.: 5 - cast, 6 - details of the cast (positive hyporelief) Рис. 5-6. Charnia ivantsovi Grytsenko sp. nov.: 5 - відбиток, 6 - деталь відбитку (позитивний гіпорельєф).

Fig. 7. Bernashevia einori Grytsenko gen. et sp. nov. Рис. 7. Bernashevia einori Grytsenko gen. et sp. nov.
Fig. 8. Amorphia incognita Grytsenko gen. et sp. nov. Рис. 8. Amorphia incognita Grytsenko gen. et sp. nov. Fig. 9. Cocardia valerii Grytsenko gen. et sp. nov. Рис. 9. Cocardia valerii Grytsenko gen. et sp. nov. Fig. 10. Dactyloichnus finkoi Grytsenko gen et sp. nov. Рис. 10. Dactyloichnus finkoi Gryt- senko gen et sp. nov. Fig. 11. Komarovia olgae Grytsenko gen. et sp. nov. Рис. 11. Komarovia olgae Grytsenko gen. et sp. nov.

Fig. 12, 13. Lomoziella menasovi Grytsenko gen. et sp. nov.: 12 - positive cast, 13 - negative cast. Рис. 12, 13. Lomoziella menasovi Grytsenko gen. et sp. nov.: 12 - позитивний відбиток, 13 - негативний відбиток.

Fig. 14. Virgatia leonidi Grytsenko gen. et sp. nov. Рис. 14. Virgatia leonidi Grytsenko gen. et sp. nov.

Fig. 15. Yuria ovalia Grytsenko gen. et sp. nov. Рис. 15. Yuria ovalia Grytsenko gen. et sp. nov. 

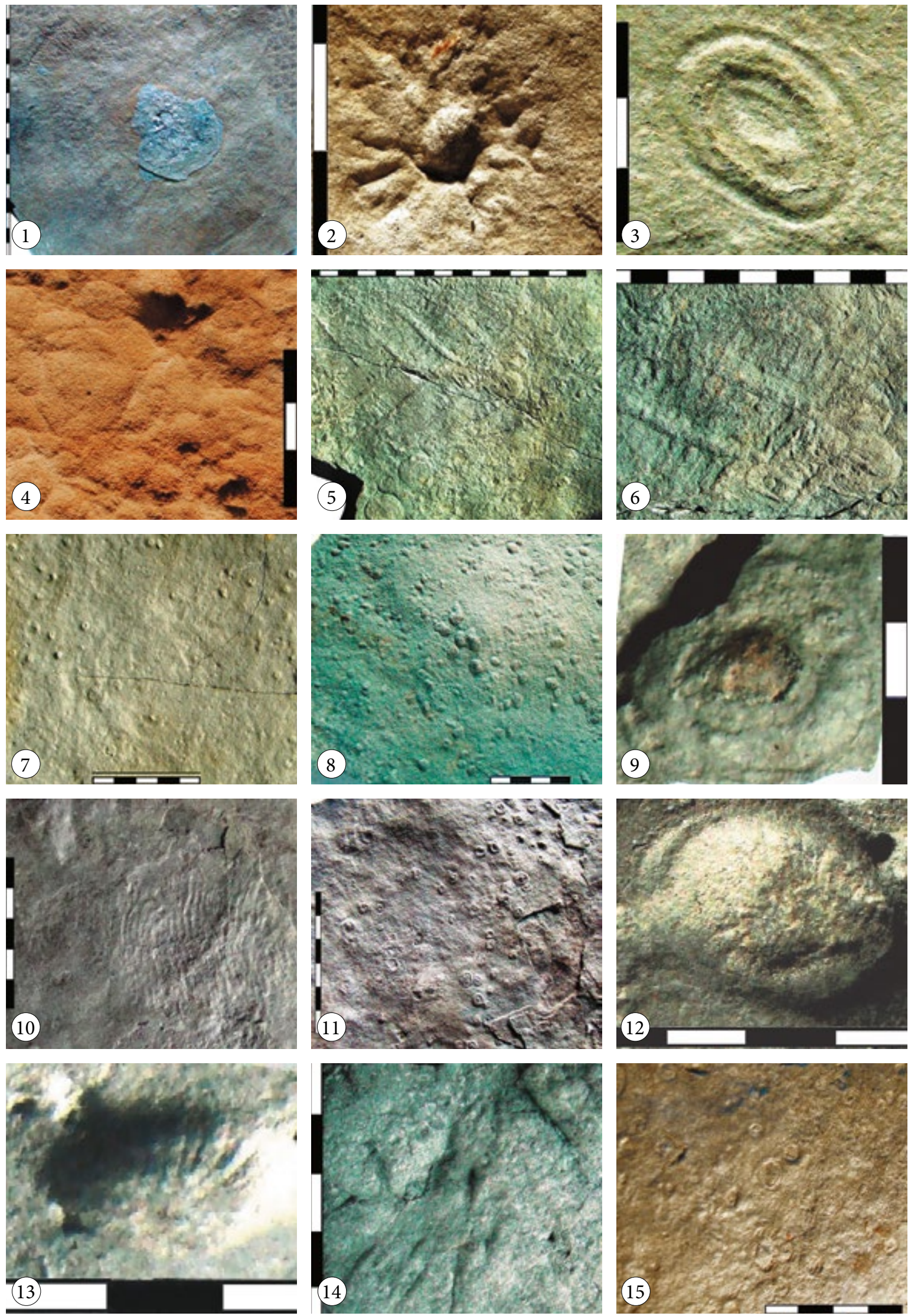

ISSN 2219-7516 Вісник Національного науково-природничого музею. 2016, том 14 

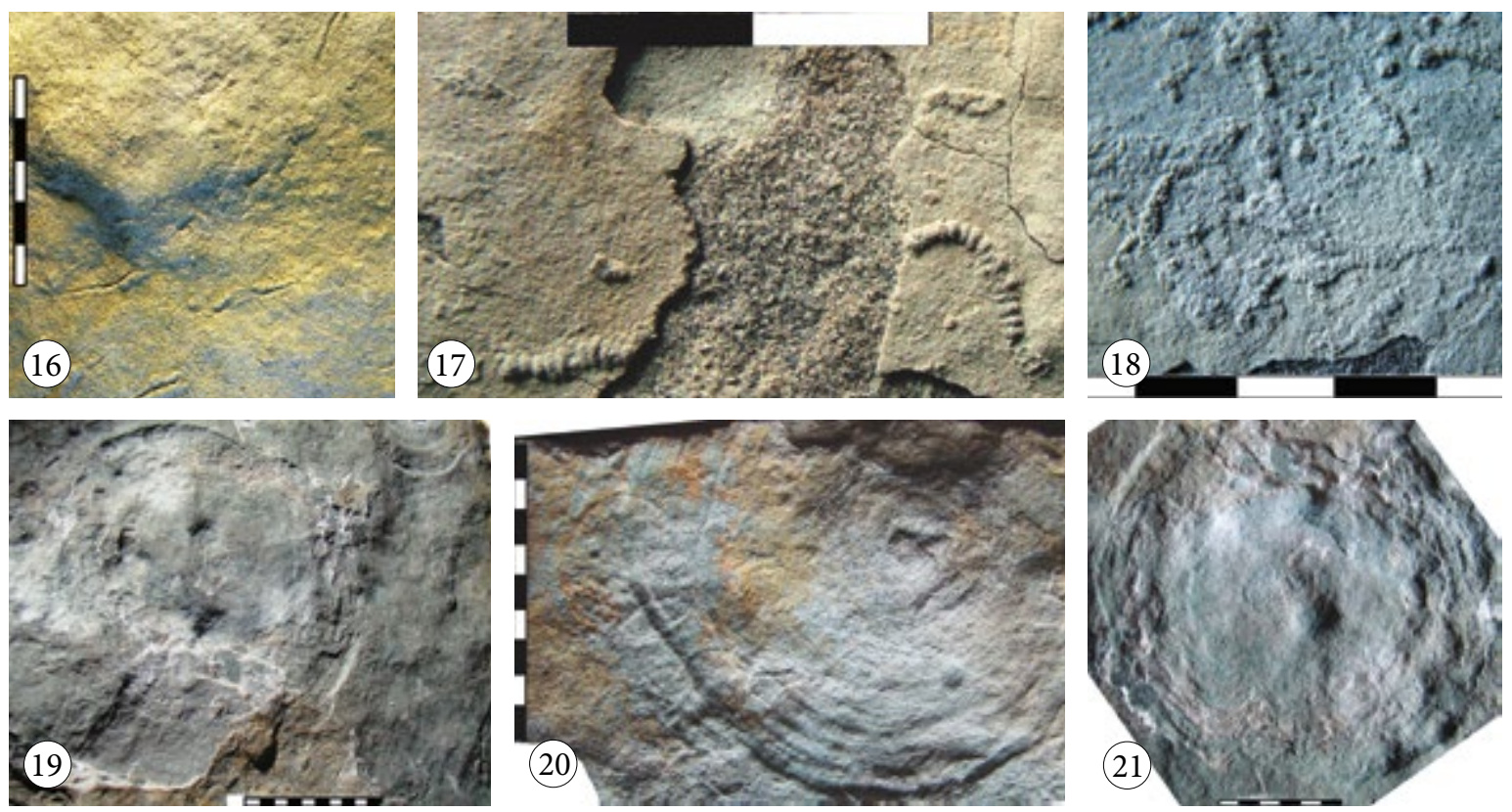

Fig. 16. Didymaulichnus nerodenkoi Grytsenko ichnosp. nov. Pис. 16. Didymaulichnus nerodenkoi Grytsenko ichnosp. nov.

Fig. 17. Paleopascichnus delicatus Palij possess a different state of preservation on the same tracks. Рис. 17. Paleopascichnus delicatus Palij має різний вигляд збереженості того самого сліду.

Fig. 18. Track of $P$. delicatus, which lost its usual form in the same layer.

Fig. 18. Слід $P$. delicatus, втратив притаманні виду ознаки в тому самому шарі.
Fig. 19-21. "Charniodiscus":

19 - three molds on one plate,

20 - the smallest mold,

21 - the biggest mold; all conserved as negative epirelief on the bed's uneven surface.

Рис. 19-21. "Charniodiscus":

19 - три відбитки на одній плиті,

20 - найменший,

21 - найбільший; всі у вигляді негативного епірельєфу на одному шарі з нерівною поверхнею.

Remarks. The name was given in honor of memory of Valery Zaika-Novatsky — professor of Taras Shevchenko Kyiv National University, who was one of the very first scientist investigating the Vendian on Podillia (Заика-Новацкий и др., 1968, Заика-Новацкий, Палий, 1968, 1974).

Original. Coll. No. 2514-23.

Dactyloichnus finkoi Grytsenko ichnogen. et ichnosp. nov. (Fig. 10)

Description. It is a series of bacterial mat imprints with traces of eating. The animal feeding with the mat has not discovered yet. Graphic marks are weakly tortuous and left imprints on the layer's bottom surface. The distance between the marks is about $2 \mathrm{~mm}$.

Remarks. Imprints look like human fingerprints and this was the reason for creating the generic name Dactyloichnus. The species name was given in honor of Sergiy Finko - a nonprofessional collector of samples of Vendian animal imprints and ichnofossils.

Original. Coll. No. 2514-255.

\section{Genus Komarovia Grytsenko gen. nov.}

Diagnosis. Little rounded imprints with an arch in their central zone. They created communities of separated and connected disks.

Remarks. The generic name was given in honor of Olga Komarova. She was a lecturer on paleontology at Taras Shevchenko Kyiv National University. 
Komarovia olgae Grytsenko gen. et sp. nov. (Fig. 11)

Description. Imprints of small "polyps" have size 3-6 mm in diameter. They form hard communities of separated and connected disks, which have complicated relief structure. The central arch and the peripheral ring are divided by an annular hollow. The connected disks are deformed.

Comparison. I could not find forms with similar characters yet. Representatives of the genus Nimbia Fedonkin are quite similar, however much bigger and have only exterior ring. Nimbia dniesteri Fedonkin also had ability to gemmation (Федонкин, 1985, Fedonkin, 1992; Fedonkin et al., 2007).

Remarks. The animals formed communities. The species name is derived from the name Olga.

\section{Genus Lomoziella Grytsenko gen. nov.}

Holotype. Lomoziella menasovi Grytsenko gen. et sp. nov., coll. No. 2489-393-1, 2.

Diagn ose. The casts of oval polyps have marks of mesentery folds.

Locality. Podillia, Bernashivka quarry on the left bank of the Dniester River.

Stratigraphic position. Vendian, Mohyliv-Podilsky series (group), Mohyliv suite (formation), Lomoziv beds.

Original. Coll. No. 2489-393-1, 2 (three-dimensional cast and mould).

\section{Lomoziella menasovi Grytsenko gen. \& sp. nov. (Fig. 12, 13)}

Description. Oval-shaped "polyps" have narrow shelf near the cap. The cast's length is $30 \mathrm{~mm}$, width $-20 \mathrm{~mm}$, depth $-15 \mathrm{~mm}$. Mesentery folds are distinguishable on both samples. It is impossible to calculate the total account of folds because of the samples' bad preservation. However, the remains of the cast's upper part and mould (Fig. 12,13) are rather in good state. There are 7 folds on $10 \mathrm{~mm}$. The folds belong to the same order. Intermediate edges are invisible. Casts were found in siltstone; it is represented by a thin grained sandstone filling up the holes remained from the animals. Remarks. The species is represented by two moulds. The holotype includes a cast and a mould of the same cast. Perhaps, these casts were unknown before. It could be a mold of a coral polyp. The species name is derived from family name Menasova. She occupies docent position at Taras Shevchenko Kyiv National University of Kyiv.

Virgatia leonidi Grytsenko gen. et sp. nov. (Fig. 14)

Description. A fragment of the cast is represented by rhizoids of an unknown animal. A part of the imprint with three distinct fissures is preserved on the plate, which is corresponds to dichotomy attaching roots. Its length is $50 \mathrm{~mm}$ and the width is near $1 \mathrm{~mm}$. They undulate insignificantly along the directions of roots.

Remarks. The generic name reflects the characters of the cast (dichotomy). The species name was given in honor of Leonid Konstantinenko. He was a famous paleontologist, an expert on trilobites and stratigraphy from Vendian to Paleozoic of Podillia.

Original, coll. No. 2489-808.

Yuria ovalia Grytsenko gen. et sp. nov. (Fig. 15)

Description. Oval casts are preserved as negative and positive imprints on the surface of the layer. Thirty eight more or less distinct specimens left imprints on a plate, which size is $10 \times 12 \mathrm{~cm}$. The small ones are rounded of size near 5-7 $\mathrm{mm}$ in diameter. The bigger ones $(10 \times 13 \mathrm{~mm})$ are oval. The relief on both type specimens is the same: rounded or oval fissure surrounding the weak central space; the latter holds more area with growth, but the fissure's width remains the same.

Remarks. The generic name was given in honor of Yuri Gureev (Гуреев, 1983-a, 1983-6). The species name reflects the oval outline of the larger cast.

Original. Coll. No. 2514-1959. Stratigraphical position: Vendian, Mohyliv-Podilsky series (group), Mohyliv suite, Lomoziv beds. 
Didymaulichnus nerodenkoi Grytsenko ichnosp. nov. (Fig. 16)

Description. Straight and weakly curved swelling traces with fissures in the center. The length of the traces is from 12 up to $20 \mathrm{~mm}$. The maximum width is $6 \mathrm{~mm}$. The swelling edges are irregular or somewhere could become fuzzy. The traces sustain approximately common directions with near $80^{\circ}$ of dispersion.

Comparison. The new species differs from Didymaulichnus tirasensis Palij and from the described by Yu. Gureev Didymaulichnus cf. miettensis Young, 1972 with smaller size and its outline in cross section.

Remarks. Didymaulichnus tirasensis Palij was found in the Baltic series, Khmelnitskiy suite (formation) (Палій, 1974, Палий, 1976). Didymaulichnus cf. miettensis Young was discovered by Gureev in Vendian, Mohyliv-Podilsky series (group), Mohyliv suite (formation), Lomoziv beds.

Original. Coll. No. 2514-1919-a. Stratigraphical position: Vendian, Mohyliv-Podilsky series (group), Mohyliv suite (formation), Lomoziv beds.

\section{Taphonomy}

The most ancient deposits of Podillia are represented by volcanic and volcano-clastic rocks correlating with the lower Vendian. Terrigenous sediments correlate mostly with the upper Vendian. Some levels of the succession are empty of macrofossils and ichnofossils. Thinbedded layers (siltstones and clayey siltstones) provide better conditions for fossil conservation. Somewhere the conservation was possible in fine-grain sandstone. The best result we could see if sedimentation has interrupted characteristics, i.e. the next layer covers the underlying rocks after solidification. Pulsing sedimentation is especially common for the shallow-water part of the basin and for near island shelves. Sometimes we could meet a special structure ("tidal sigmoid"), which is usual for ultimate shallow-water conditions. The imprints are better conserved on clay in basin parts without turbulence and bioturbation.

\section{Special features of preservation}

The tracks and imprints (casts) were conservated on both surfaces of the layers. The upper surface of the lower layer usually has negative structure, but the lower layer of the upper one is positive. Tracks and casts on soft surfaces could undergo changes (e.g. deformation connected with slide movement of sediments). The deformation can change the view of the structure up to unrecognizability. For example, we could see some changed tracks of herding Paleopascichnus delicatus Palij from the upper part of the Yampil beds in the quarry near Bernashivka village (Палий, 2011). The tracks were preserved on the layers' upper surface as positive relief. Curiously, some track fragments have good preservation, but others got an unclear relief (Fig. 17, 18). They clearly differ from the other tracks (Pickerill, 1991).

The quarry observation was carried out on transitional step of its excavation, when the beds of coarse-grain sandstone covered by ripples of current on the top were clearly outcropped. It proves active water movement here during the Lomoziv time, which was a reason for improvement of the environment and animal diversity. Generally, the Lomoziv beds in the quarry have less thickness and more layers of coarse grain sandstone, because they are closer to the shoe then the stratotype outcrop. It seems that locations situated closer to the shoe determine more diversity and population density.

Sometimes imprints remain on sands. The diagenetic changes alternated sand sediments of the Yampil beds into hard sandstone with massive structure. To collect fossils from such rocks is problematic, although explosions cut massive sandstones into big plates just by the bedding surfaces, which match the levels of Nemiana simplex communities (Палий, Пости, Федонкин, 1979, Paliy, Posti, Fedonkin, 1983, Палій, 2011).

Three rounded molds were found on one big sandstone plate with uneven bedding surface. The molds have many almost concentric lines and unclear negative central structure (Fig. 19-21.

Probably, there are big discs of attaching hypothetic petalonama (?). The smaller one is near $10 \mathrm{~cm}$ in diameter, while the biggest one is more than $20 \mathrm{~cm}$. 
D. Pylypenko was the first who found the described here Charnia ivantsovi Grytsenko sp. nov. The specimen was located on the same level with imprints of Nemiana simplex Palij (Fig. 5, 6). Sometimes the samples with communities of Nemiana simplex Palij can be found even on current ripples

\section{Discussion}

Exploration, description and further museum conservation are very important stages of studying of the vendobionts. Their first discovery in Podillia was done by A.V. Krasowsky (Красовский, 1916) and O.K. Kaptarenko (Каптаренко, 1928). These authors proposed an organic origin of lens-like fossils in the "Cambrian age" or before the "Silurian age" stratum spreading along the Dniester River. In modern stratigraphical schemes, it is the Vendian system, Mohiliv-Podilsky series, Mohyliv suite, Yampil beds.

Since 1966, many scientists have elaborated paleontological characteristics of the whole Vendian sequence. Zaika-Novatsky, Sokolov (Заика-Новацкий, 1971; Гуреев, 1983 a, b; Соколов, Федонкин, 1985; Fedonkin, 1992 a, b; Соколов, 1997; Палий, 1969, 1974, 1976, 2011; Палий, Пости, Федонкин, 1979; Paliy, Posti, Fedonkin, 1983; Fedonkinn, Gehling, Grey et al., 2007) and others took part in discoveries and descriptions of the Vendian fossils from Podillia. A. Martyshin is one of the fossil diggers having opportunity to collect some Vendian fossils in the quarry near the Dniester Electricity power station's dam in the Mohiliv formation (Lomoziv and Yampil beds: Yorgia, Ovatoscutum, Chondroplon, Andiva, "Spriggina" borealis, Arumberia (Мартишин, 2012). Such fossils were firstly discovered in the Ediacara of Australia and near the White Sea's coast. The authors without any proofs considered that the track fossils of Harlaniella, Calyptrina, Somatohelix and Shaaxilithes are not tracks of vital activity, but are some tubulated animals. Such interpretation is probably a speculation having no basement (Нестеровский, Мартишин, Огар, 2015).

A monograph with the list and description of all known Vendian fossils from Podillia was published in 2015 (Иванцов, Гриценко, Палий, 2015). Some important specimens of vendobionts and newly discovered fossils are in private collections out of any expert attention. So-called "fossil diggers" have opportunity to visit the quarry immediately after explosions. They collect and try to sell fossils as contraband abroad.

The first discovery of fossils in the hydroelectric power station's excavation machine hall on the right bank of the Dniester River and in the quarry was presented by M. Fedonkin in 1985 and 1992 (Федонкин, 1985, 1992 a, b). A new fossil-bearing locality was found on the river's left bank in the quarry, where the excavation of stones has started later. A lot of building material were needed for construction of the dam, roads etc. Sandstone and granite were used in any case. Siltstones from the Lomoziv beds and clayey sediment rocks of the Liadova beds were located near the quarry. Thus, the quarry became broader and deeper. The new horizons were opened for facial study and crop collection. The explosions created micro-fissures along the bedding surfaces. Consequently, the rocks were easily broken into plates with tracks of ichnofossils or animal imprints.

The discussed quarry is a place of geological interest for many reasons. A lot of different casts, tracks and others facial evidence were found there and proved the conditions of paleoenvironment. The author consider that sedimentary structures such as current ripples and tidal sigmoid firmly suggest shallow-water conditions. On the other hand, clayey sediments with pyrite concretions could be evidence for deep water conditions with hydrogen sulphide contamination. The availability of bentonite clays is considered to prove volcanic eruption directly in the basin or not far from it. Thick bentonite layers were found in the Liadova beds of the Mohyliv suite and the Bernashivka beds of the Yarishiv suite. A great volcanic explosion had happened during the Bronnitsa time, which is proved by the silicification and hyaloclastic material in the rocks of the Bronnitsa beds. Important geological data were obtained during investigation of mineralogical diversity, which reflects hydrothermal processes of low temperature. Pyrite, fluorite, calcite and galenite in veins among granite were found. Thus, the evidence of geological diversity concentrated in one place could be a reason to declare it as a place of geological heritage of international value. 


\section{Conclusions}

Specifics of finding of Vendian fossils characterize certain facial conditions. Broad variations of rocks and the huge amount and area of excavations provide us opportunity to find a plenty of new species, some of which were described here. The new findings of "vendobionts" in the quarry expands the list of inhabitants of the Podillian Sea during the Vendian. The new species were related to the benthos, which was sedentary and agile. No real jellyfish were found yet. Some conclusions about the palaeoenvironmental conditions, taphonomy and systematic questions of ancient animals are often used without deeply detailed study of factual materials. In any case, this locality is proposed to be declared as an object of international geological heritage.

\section{Acknowledgements}

I express the deepest thanks to my late teachers - V. S. Zaika-Novatskiy, O. V. Komarova, V. M. Nerodenko, D. S. Sergeev, O. L. Einor establishing my fondness to paleontology. I am also sincerely grateful to colleagues from Ukraine - V. M. Paliy, V. Ya. Velikanov, P. D. Tsegelnyuk, V. I. Poletaev, O. M. Khanisenko, D. M. Drygant and late L. I. Konstantinenko, who adjoin me in Vendian fossil investigation, as well as to foreign colleagues- P. D. Boukatchuk from the Republic of Moldova, O. B. Bondarenko (Lomonosov State University), B. S. Sokolov and A. Yu. Ivantcov (Borissiak Paleontological Institute of the Russian Academy of Sciences) from Russia, Paul Copper (Laurentian University, Canada) and others I spend field work with them during many years.

This study was accomplished under the support of State foundation for Basic Research of Ukraine (grant no. 53/111-2013 in 2013). Further field works (2014-2016) were supported under the grant "Conservation of National Heritage" at the National Natural History Museum NAS of Ukraine.

\section{References}

Великанов, В. А., Асеева, Е.А., Федонкин М. А. Венд Украины. - Киев : Наукова думка, 1983. - 162 с.

[Velikanov, V. A., Aseeva, E. A., Fedonkin, M. A. Vendian of Ukraine. - Kyiv : Naukova Dumka, 1983. (in Russian)].

Великанов, В. А. Опорный разрез венда Подолии // Вендская система. Историко-геологическое и палеонтологическое обоснование. - Москва : Наука, 1985. - Том 2 (Стратиграфия и геологические процессы). - C. 35-67.

[Velikanov, V. A. The referent section of Vendian of Podillia / Vendian System. Geological, Historical and Paleontological Basement. - Moskwa : Nauka, 1985. - Vol. 2 (Stratigraphy and Geological Activity). - P. 3567. (in Russian)].

Веліканов, В. Я. Український гіпостратотип вендської системи // Геологический журнал. - 2011. № 1 . - C. 42-49.

[Velikanov, V. A. Ukrainian hypostratotyp of Vendian System // Geological Journal. — 2011. - N 1. - P. $42-49$. (in Ukr.)].

Заика-Новацкий, В. С., Великанов, В. А., Коваль, А. П. Первый представитель эдиакарской фауны в венде Русской платформы (верхний докембрий) // Палеонтологический журнал. - 1968. — № 2. - С. $133-134$.

[Zaika-Novatskiy, V.S., Velikanov, V. A., Koval', A. P. The first representative of Eiakaran Fauna in Vendian Russian Platform (Upper Precambrian) // Paleontological Journal. - 1968. - N 2. - P. 133-134. (in Russian)].

Заика-Новацкиц̆, В. С., Палий, В. М. Новые данные относительно проблематических отпечатков из вендских отложений Подолии // Палеонтол. сборник Львовского университета. - 1968. - № 5, вып. 1. - C. 130-135.

[Zaika-Novatskiy, V. S., Paliy, V. M. New data about problematic imprints from Vendian deposits of Podillia // Paleontol. Collection of Lviv University. — Lviv : Vyshcha Shkola, 1968. - N 5, is. 1. - P. 130-135. (in Russian)].

Заика-Новацкиц̆, В. С., Палиц̆, В. М. Древнейшие ископаемые организмы в отложениях вендского ком плекса Приднестровья // Палеонтол. сборник Львовского университета. - 1974. — № 11, вып. 1. — C. 59-65.

[Zaika-Novatskiy, V. S., Paliy, V. M. The oldest fossils in Vendian complex deposits in near Dniester area // Paleontol. Collection of Lviv University. — Lviv : Vyshcha Shkola, 1974. - N 11. — P. 59-65. (in Russian)].

Гуреев, Ю. А. Фаунистические остатки и следы жизнедеятельности беспозвоночных, их стратиграфическая приуроченность к разрезу верхнего докембрия - нижнего кембрия Среднего Приднестровья // Ископаемая фауна и флора Украины. - Киев : Наукова думка, 1983 a. - C. 34-39.

[Gureev, Yu. A. Fossil imprints vital activity of invertebrate animals and their stratigraphical position in succession Upper Precambrian - Lower Cambrian at Middle Dniester area // Fossil Fauna and Flora of Ukraine. - Kyiv : Naukova Dumka, 1983 a. - P. 34-39. (in Russian).] 
Гуреев, Ю. А. О новой форме ископаемых следов из нижнебалтийских отложений Подольского Приднестровья // Палеонтол. сборник Львовского университета. - Львов: Вища школа, 1983 б. № 20. - C. 70-73.

[Gureev, Yu. About new ichnofossils from Lower Baltic deposits Podillian near Dniester area // Paleontol. Collection of Lviv University. — Lviv: Vyscha Shkola, 1983 b. — N 20. - P. 70-73 (in Russian).]

Иванцов, А. Ю., Гриценко, В. П., Палий, В. М. и др. Макрофоссилии верхнего венда Восточной Европы (Среднее Приднестровье, Волынь) - Москва : ПИН РАН, 2015. - 144 с.

[Ivantsov, A. Yu., Grytsenko, V. P., Paliy, V. M. et. al. Upper Vendian Macrofossils of Eastern Europe. - Moskwa : PIN RAS, 2015. - 144 p. (in English and Russian).]

Каптаренко, О. К. Загадкові копальні форми з силурських пісковиків Західного Поділля // Труди Українського наук.-досл. геол. ін.-ту, 1928. - Т. 2. - С. 87-103.

[Kaptarenko, O. K. Enigmatic fossil forms from Silurian sands of Western Podillia // The Proceeding of Ukrainian Research Geological Institute. - Kyiv, 1928. - Vol. 2. - P. 87-103. (in Ukrainian).]

Кирьянов, В. В. Кирьянов, В. В. Современное состояние проблеми границы докембрия-кембрия на Восточно-Европейськой платформе // Проблемы создания шкалы геологического времени докембрия и фанерозоя Украины. - Киев : ИГН АН Украины, 1993. - С. 47-52.

[Kiryanov, V. V. The Precambrian-Cambrian state-of-the-boundary problem on East-European platform // Problem of creation Geological time scale for Precambrian, Cambrian and Fanerozoan of Ukraine. - Kyiv : Institute of Geological Science of Acad. Sci. of Ukraine, 1993. - P. 47-52. (in Russian).]

Коренчук, Л. В. Стратотипические разрезы могилев-подольской серии венда Приднестровья. Киев : ИГН АН Украины, 1981. - 56 с.

[Korenchuk, L. V. The Stratigraphical Sections of Vendian Mohyliv-Podil'skiy Seria at Near Dniester Area. Kyiv : IGS AS Ukraine. - 1981. - 56 p. (in Russian).]

Красовский, А. В. Из геологических наблюдений в Подольской губернии (предварительное сообщение) // Записки Императ. о-ва. любителей естеств., антроп. и этн. Геол. отд. - 1916. - Том 3. - С. $22-27$.

[Krasovsky, A. V. From Geological Observations in the Podolian Region (preliminary report) // Transaction of Imperat. Society of Amateurs of Natural History. Antropol. Etnogr. Geol. Department. — 1916. — Vol. 3. — P. 22-27. (in Russian).]

Мартишин, A. О. Едіакарська фауна ямпольських пісковиків венду Подолья // Геолог Украины. 2012. - № 4. - C. 97-104.

[Martyshyn, A. O. Ediakarian fauna at Vendian Yampil sandstones of Podillia // Geologist of Ukraine. 2012. - N 4. - P. 7-104. (in Ukrainian).]

Нестеровский, В. А., Мартишин, А. I., Огар В. В. Деякі стратиграфічні рівні знаходження скам'янілостей у верхньому венді Поділля // Природничі музеї та їх роль в освіті і науці : Матеріали Міжнародної наукової конф. - Київ, 2015. - С. 78-80.

[Nesterovskiy, V. A., Martyshin, A. I., Ogar, V. V. Some stratigraphic levels of fossils in Upper Vendian of Podillya region // Natural History Museums and their Role in Education and Science : Proc. Intern. Conf. (27-30 October 2015. - Kyiv, 2015. - P. 78-80. (in Ukrainian).]

Палиц̆, В. М. О новом виде цикломедуз из венда Подолии // Палеонтол. сборник Львовского университета. - Львов: Вища школа, - 1969. - № 6, Вып. 1. - С. 110-113.

[Paliy, V. M. About new species of cyclomedusa from Vendian of Podillia // Paleontol. Collection of Lviv University. - Lviv: Vyshcha shkola, 1969. - N 6, is. 1. - P. 110-113. (in Russian).]

Палій В. М. Подвійні сліди (білобіти) у відкладах балтійської серії Придністров’я // Доповіді АН УРСР, Серія Б. - 1974. - № 6. - C. 499-503.

[Paliy, V. M. The Double tracks (bilobites) at Baltic series sediments of Near Dniester area // The Reports of AN UkrRSR, ser. В. - 1974. - N 6. - P. 499-503. (in Ukrainian).]

Палиц̆, В. М. Остатки бесскелетной фауны и следы жизнедеятельности из отложений верхнего докембрия и нижнего кембрия Подолии // Палеонтология и стратиграфия верхнего докембрия и нижнего палеозоя юго-запада Восточно-Европейской платформы. — Киев : Наукова думка, 1976. — C. 63-77.

[Paliy, V. M. Remnants of non-skeleton fauna and tracks of vital activity in Upper Precambrian and Lower Cambrian of Podillia // Paleontology and Stratigraphy Upper Precambrian and Lower Cambrian of South-West East European platform. - Kyiv : Naukova dumka, 1976. - P. 63-77. (in Russian).]

Палій, В. М. Унікальні палеонтологічні знахідки у відкладах венду та нижнього кембрію Середнього Придністров’я // Геолог України. - 2011. - № 3-4 - С. 85-88.

[Paliy, V. M. Unique paleontological discoveries in deposites of Vendian and Lower Cambrian of Middle Dniester area // Geologist of Ukraine. - 2011. - N 3-4 - P. 85-88. (in Ukrainian).]

Палий, B.M., Пости Е.,Федонкин, М. А. Мягкотелые метазоа и ископаемые следы животных венда и раннего кембрия // Палеонтология верхнедокембрийских и кембрийских отложений ВосточноЕвропейской платформы. - Москва : Наука, 1979. - С. 49-82.

[Paliy, V. M., Posti, E., Fedonkin, M. A. Vendian and Early Cambrian softbody metazoan and ichnofossils / Paleontology of Upper Precambrian and Cambrian Deposits of East-European Platform. — Moskwa : Nauka, 1979. - P. 49-82. (in Russian).] 
Соколов, Б. С. Очерки становления венда. - Москва : КМК Scientific Press Ltd., 1997. - 154 с.

[Sokolov, B. S. Sketches of Vendian Development. - Moskwa : KMK Scientific Press Ltd, 1997. - 154 p. (in Russian with English summary, p. 94-98).]

Соколов, Б. С., Федонкин, М. А. (ред.) Вендская система. Историко-геологическое и палеонтологическое обоснование. - Москва: Наука, 1985. - Том 1: Палеонтология. - 221 с.

[Sokolov, B. S., Fedonkin, M. A. (eds.). Vendian system. Geological, Historical and Paleontological Basement. Moskwa : Nauka, 1985. - Vol. 1: Paleontology. - 221 p. (in Russian)].

Соколов, Б. С. Вендский этап в истории Земли // XXIV Сессия Междунар. геол. конгр. Докл. сов. геол. - Москва: Наука, 1972. - С. 114-125.

[Sokolov, B. S. Vendian period in the Earth history // Proc. XXIV Session Intern. Geol. Congr. - Moskwa, 1972. - P. 114-125. (in Russian)].

Федонкин, М. А. Систематическое описание вендских Metazoa // Вендская система. Историко-геологическое и палеонтологическое обоснование. - Москва : Наука, 1985. - Том 1: Палеонтология. C. $70-106$.

[Fedonkin, M. A. Systematic description of Vendian Metazoa / Vendian system. Hystoric, Geological and Paleontological Foundation. - Moskwa : Nauka, 1985. - Vol. 1: Paleontology. - P. 70-106. (in Russian).]

Antcliffe, J. B., Brasier, M. D. Charnia and seapens are poles apart // Journal of the Geological Society. - London, 2007. - Vol. 164. - P. 49-51.

Brasier, M. D., Antcliffe, J. B. Decoding the Ediacaran Enigma // Science. - 2004. - Vol. 305, Is. 5687. P. 1115-1117.

Fedonkin, M. A. Vendian body fossils and trace fossils // Behgtson, S. (ed.). Early Life Earth. - New York : Columbia University Press, 1992 a. - P. 370-388.

Fedonkin, M. A. Vendian Faunas and the Early Evolution of Metazoa // Lipps, J. H., Signor, P. W. (eds.). Origin and the Early Evolution of Metazoa. - New York : Plenum Press, 1992 b. - P. 87-129.

Fedonkin, M. A., Gehling, J. G., Grey, K. et al. The Rise of Animals: Evolution and Diversification of the Kingdom Animalia. - Baltimore : Johns Hopkins University Press, 2007. - 326 p.

Paliy, V. M., Posti, E., Fedonkin, M. A. Soft-bodies Metazoa and animals trace fossils in the Vendian and Early Cambrian // Upper Precambrian and Cambrian Palaeontology of the East-European Platform. - Warszawa : Wydawnictwo geologiczne, 1983. - P. 56-94.

Pickerill, R. K. The trace fossil Neonereites multiserialis Pickerell and Harland, 1988 from the Devonian Warske Formation, northwest Brunswick // Atlantic Geology. — 1991. — Vol. 27. — P. 119-126.

Нові знахідки відбитків м'якотілих та іхнофосилій у Могилівській світі Бернашівського кар'єру. Гриценко, В. П. - Відомо, що вендські відклади Поділля складали конкуренцію едіакарським розрізам щодо обрання стратотипу останньої системи верхнього протерозою. Розрізи відслонені берегами Дністра та його приток, але найкращий об'єкт для дослідження - кар'єр поблизу с. Бернашівка. Науковці та шукачі викопних решток знаходять зразки нових видів вендської біоти. Шукачі скам'янілостей знаходяться навіть у кращих умовах, оскільки не залежать від жодної адміністрації та інститутів. Об'єктами вивчення були різні види викопних решток (переважно відбитки Metazoa, сліди іхнофосилій або біогліфи), знайдені на декількох рівнях вендської послідовності в межах могилів-подільської серії. Нові роди та види описані за прийнятим для вендських викопних решток спрощеним стандартом, що визначається ступенем їх збереженості та простотою будови. Вперше знайдені та описані об’ємні відбитки істот, невідомих раніше з цієї території - «поліпи кишковопорожнинних» (на зліпках помітні повздовжні зморшки, які подібні до мезентеріальних складок коралів. У 2016 р. на Поділлі вперше у ямпільських верствах знайдено відбитки Charnia masoni Ford та sp. nov. p. (ймовірно, представники двох різних видів чи особин різного віку. На додачу до викопних решток досліджувалися також фаціальні особливості вміщуючих відкладів. Встановлено різноманітність умов накопичення морських відкладів від мілководних до глибоководних. Викопні рештки розповсюджені переважно у мілководних відкладах.

Ключові слова: венд, верхній протерозой, Поділля, могилівська світа, нові роди, нові види.

Адреса для зв'язку: В. П. Гриценко; Національний науково-природничий музей НАН України; вул. Богдана Хмельницького 15, Київ, 01030 Україна; e-mail favosites@ukr.net 